ORIGINAL ARTICLE

\title{
Circumcision for the prevention of urinary tract infection in boys: a systematic review of randomised trials and observational studies
}

\author{
D Singh-Grewal, J Macdessi, J Craig
}

See end of article for authors' affiliations

Correspondence to: Jonathan Craig, Centre for Kidney Research, Clinical Sciences Building, Locked Bag 4001, Westmead NSW 2145, Sydney, Australia; jonc@health. usyd.edu.au

Accepted 9 August 2004

Published Online First 12 May 2005

Objective: To undertake a meta-analysis of published data on the effect of circumcision on the risk of urinary tract infection (UTI) in boys.

Data sources: Randomised controlled trials and observational studies comparing the frequency of UTI in circumcised and uncircumcised boys were identified from the Cochrane controlled trials register, MEDLINE, EMBASE, reference lists of retrieved articles, and contact with known investigators.

Methods: Two of the authors independently assessed study quality using the guidelines provided by the MOOSE statement for quality of observational studies. A random effects model was used to estimate a summary odds ratio (OR) with $95 \%$ confidence intervals (CI).

Results: Data on 402908 children were identified from 12 studies (one randomised controlled trial, four cohort studies, and seven case-control studies). Circumcision was associated with a significantly reduced risk of UTI (OR=0.13; $95 \% \mathrm{Cl}, 0.08$ to $0.20 ; p<0.001)$ with the same odds ratio $(0.13)$ for all three types of study design.

Conclusions: Circumcision reduces the risk of UTI. Given a risk in normal boys of about $1 \%$, the numberneeded-to-treat to prevent one UTI is 111 . In boys with recurrent UTI or high grade vesicoureteric reflux, the risk of UTI recurrence is $10 \%$ and $30 \%$ and the numbers-needed-to-treat are 11 and 4 , respectively. Haemorrhage and infection are the commonest complications of circumcision, occurring at rate of about $2 \%$. Assuming equal utility of benefits and harms, net clinical benefit is likely only in boys at high risk of UTI.

C ircumcision is the commonest surgical procedure carried out on children. ${ }^{1}$ Neonatal circumcision rates widely between different cultures, with rates as high as $64 \%^{2}$ in North America, between $10 \%$ and $20 \%$ in Australia, ${ }^{3}$ and far lower rates in Europe and Asia. ${ }^{2}$

Boys have been circumcised for thousands of years and circumcision plays a significant cultural and religious role in many societies. It is also undertaken on medical grounds with benefits thought to include improved hygiene, a reduced incidence of urinary tract infection (UTI), ${ }^{4-6}$ sexually transmitted diseases, ${ }^{7}$ penile cancer, ${ }^{8}$ and phimosis, ${ }^{9}$ and a reduction in the incidence of human papilloma virus related cervical cancer in female sexual partners. ${ }^{10}$

The overall complication rate of circumcision is between $2 \%$ and $10 \%,{ }^{11}{ }^{12}$ and most complications are minor. ${ }^{11}{ }^{13}{ }^{14}$ While haemorrhage is the most frequent acute complication, infection, glandular ulceration, urethral fistula formation, and penile amputation can also occur. ${ }^{11}$ Long term complications include meatal stenosis and poor cosmetic results. ${ }^{11}$

Various paediatric societies have developed position statements on circumcision. These statements generally conclude that there is insufficient evidence to recommend routine neonatal circumcision but consider it justified in recurrent balanitis, true phimosis, and UTI. ${ }^{2} 315$

Lack of a clear consensus on the magnitude of the benefits of circumcision may reflect the variability in the different methods used to search and critically appraise the available reports. ${ }^{16}$ As the most frequently cited benefit of circumcision is a reduced incidence of UTI, we have undertaken a systematic review of the available data on the effect of circumcision on UTI in male subjects of all ages.

\section{METHODS}

All steps of the review, including literature search, data extraction, and data analysis, were carried out independently by two of us (JM and DSG) without blinding to authorship. Resolution of discrepancies was by consensus and the involvement of the third author (JC) when necessary.

\section{Data sources}

The Cochrane controlled trials register (issue 4, November 2002), MEDLINE (1966 to November 2002), and EMBASE (1980 to November 2002) databases were searched.

MEDLINE and EMBASE were searched using "circumcision" as both a text word and medical subject heading $(\mathrm{MeSH})$ term. The search was not limited by language, and bibliographies of identified publications were examined for any relevant material that may have been overlooked. Details of any additional published or unpublished data were sought from authors identified in the literature search.

Following the computerised database search, all titles were screened and abstracts of relevant or possibly relevant articles were reviewed in full. Studies in languages other than English were translated before assessment. When more than one report of the same data was found, data were extracted only from the paper containing the most complete data.

\section{Study selection}

All studies examining the effect of male circumcision on UTI were included. The population of interest was male without any age restriction, and the intervention evaluated was circumcision. Diagnosis with UTI was the only outcome investigated. Studies were included only if they provided sufficient information for a $2 \times 2$ contingency table to be constructed, so that the odds of UTI in the circumcised group could be compared with those in the uncircumcised group.

Abbreviations: CONSORT, consolidated standards for reporting trials; MOOSE, meta-analysis of observational studies in epidemiology; UTI, urinary tract infection 


\section{Data extraction}

Randomised studies were assessed using the guidelines provided by the CONSORT statement. ${ }^{17}$ Aspects of study design including allocation concealment, blinding, follow up, outcome measurement, and analysis by intention to treat were assessed.

Quality assessment for observational studies was carried out using the guidelines provided by the MOOSE statement. ${ }^{18}$ The quality of studies identified was assessed according to the study setting, completeness and duration of follow up, validity and completeness of exposure and outcome ascertainment, comparability of the control group, and adjustment for known confounding variables.

\section{Data synthesis}

Statistical analysis was done with Review Manager (version 4.2). ${ }^{19}$ An odds ratio (OR) with $95 \%$ confidence interval (CI) was calculated for each individual study and a summary OR using a random effects model was first calculated for subgroups based on study type (that is, randomised controlled trial, cohort study, or case-control study) and then an overall OR was calculated across all study types if no heterogeneity was present.

Consistency of the intervention effects across studies was evaluated using the Cochran Q statistic for heterogeneity with $n-1$ degrees of freedom and an $\alpha$ of 0.05 . This method calculates a $\chi^{2}$ statistic, with $\mathrm{p}<0.05$ suggesting that the observed variation in the OR is unlikely to be a result of chance alone..$^{20}$ The $\mathrm{I}^{2}$ statistic was calculated as an estimate of the percentage of the variability in the OR due to heterogeneity rather than chance, with an $\mathrm{I}^{2}$ of greater than

Citations retrieved from MEDLINE and EMBASE $(n=2166)$



Abstracts retrieved $(n=130)$

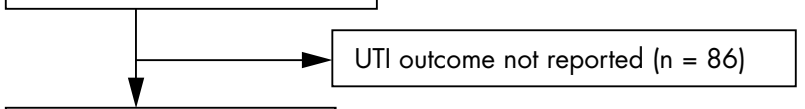

Full text retrieval $(n=44)$

\begin{tabular}{|l|} 
Articles excluded after full appraisal \\
$(\mathrm{n}=33)$ \\
- Reviews $(\mathrm{n}=19)$ \\
- Cost-benefit analyses $(\mathrm{n}=4)$ \\
- Position statements $(\mathrm{n}=4)$ \\
- Meta-analyses $(\mathrm{n}=1)$ \\
- Other $(\mathrm{n}=5)$ \\
\hline
\end{tabular}

Articles included in the systematic review $(\mathrm{n}=11)$

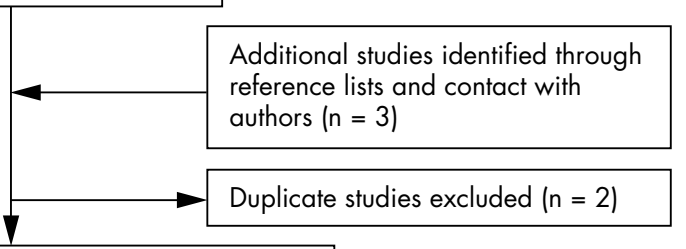

Included in final analysis $(\mathrm{n}=12)$

- Randomised controlled trial $(n=1)$

- Cohort studies $(n=4)$

- Case-control studies ( $n=7)$

Figure 1 Flow chart outlining the study selection process for the effect of circumcision on urinary tract infection.
$50 \%$ indicating significant heterogeneity. ${ }^{20}$ Heterogeneity between and within subgroups, and between individual studies when combined, was assessed. Possible sources of heterogeneity included study type, setting, study population, and follow up.

There were insufficient studies to construct a funnel plot to assess for publication bias.

\section{RESULTS}

\section{Literature search}

The study selection process is outlined in fig l. From 2166 titles and abstracts retrieved, 12 fulfilled the inclusion criteria (one randomised trial, four cohort studies, and seven casecontrol studies).

\section{Characteristics of the studies included}

The characteristics of the studies included are outlined in table 1. All were published between 1987 and 2001. Most originated from North America and relied on hospital inpatient and outpatient data. These 12 studies provided data on 402908 children and 1953 separate episodes of UTI. Most of the studies included examined UTI in infants. One included adults and four others included boys beyond the first year of life. Studies generally reported episodes of UTI rather than patients with UTI, and only one reported recurrent episodes of UTI in individual patients.

The single randomised controlled trial by Nayir ${ }^{21}$ was a study of recurrent UTI. Seventy uncircumcised patients with proven UTI were recruited and then randomised into circumcision and non-circumcision groups. UTI was defined as a positive urine culture with $>10^{8} / 1$ pure growth from a bag or clean catch specimen in the presence of urinary symptoms. The presence of urinary tract abnormality was the only exclusion criterion. Although this trial ran for 12 months, only the six months of parallel follow up was included in the systematic review as the boys randomised to the no circumcision group were circumcised at six months.

\section{Quality of the included studies}

For the single randomised trial, ${ }^{21}$ follow up was complete and analysis was by intention to treat but no details were provided about the method of randomisation, concealment of allocation, or blinding. No demographic details other than age were available for comparison between the two groups.

The quality of these studies the case-control and cohort studies was variable, with variable UTI definitions used and different methods employed to ascertain circumcision status and UTI outcome. Exclusion criteria and adjustment for confounding also varied among the studies. Only one of the cohort studies followed patients beyond one year, and in the case-control studies all controls were obtained from hospital based populations (tables 2 and 3 ).

The confounding variables that were adjusted for included age, socioeconomic status, and ethnicity. Both socioeconomic status and ethnicity were associated with circumcision status in several studies but there was no evidence of an association between these factors and UTI outcome between the circumcised and uncircumcised groups.

\section{Association between circumcision and UTI}

Figure 2 summarises the results of our meta-analysis.

Randomised controlled trial

The randomised study from Nayir ${ }^{21}$ had an OR of 0.13 (95\% CI, 0.01 to 2.63).

\section{Cohort studies}

All four cohort studies ${ }^{15622}$ showed benefit with a summary OR of 0.13 (95\% CI, 0.07 to 0.23 ). There was significant 


\begin{tabular}{|c|c|c|c|c|c|c|c|}
\hline Study design & Reference & Year & Country & Setting & $\mathrm{n}$ & $\begin{array}{l}\text { No of UTI } \\
\text { episodes }\end{array}$ & $\begin{array}{l}\text { Age (months, } \\
\text { years) }\end{array}$ \\
\hline $\begin{array}{l}\text { RCT } \\
\end{array}$ & Nayir $^{21}$ & 2001 & Turkey & Hospital outpatients & 70 & 3 & $\begin{array}{l}3 \text { months to } \\
10 \text { years }\end{array}$ \\
\hline Cohort studies & $\begin{array}{l}\text { Schoen et a }{ }^{22} \\
\text { To et al } \\
\text { Wiswell and Hachey } \\
\text { Wiswell et } a l^{5}\end{array}$ & $\begin{array}{l}2000 \\
1998 \\
1993 \\
1987\end{array}$ & $\begin{array}{l}\text { USA } \\
\text { Canada } \\
\text { USA } \\
\text { USA }\end{array}$ & $\begin{array}{l}\text { Hospital in/outpatient } \\
\text { Hospital in/outpatient* } \\
\text { Hospital inpatient } \\
\text { Hospital inpatient }\end{array}$ & $\begin{array}{l}14893 \\
58434 \\
107598 \\
219775\end{array}$ & $\begin{array}{l}154 \\
330 \\
496 \\
610\end{array}$ & $\begin{array}{l}<1 \text { year } \\
<3 \text { years } \\
<1 \text { year } \\
<1 \text { year }\end{array}$ \\
\hline \multirow[t]{2}{*}{ Case-control studies } & $\begin{array}{l}\text { Craig et } a^{23} \\
\text { Newman et } a^{24} \\
\text { Rushton and Majd } \\
\text { Spach et } a^{26}\end{array}$ & $\begin{array}{l}1996 \\
2002 \\
1992 \\
1992\end{array}$ & $\begin{array}{l}\text { Australia } \\
\text { USA } \\
\text { USA } \\
\text { USA }\end{array}$ & $\begin{array}{l}\text { Hospital in/outpatient } \\
\text { Non-hospital outpatients } \\
\text { Hospital inpatient } \\
\text { Community sexually } \\
\text { transmitted diseases clinic }\end{array}$ & $\begin{array}{l}886 \\
769 \\
86 \\
78\end{array}$ & $\begin{array}{r}144 \\
56 \\
23 \\
26\end{array}$ & $\begin{array}{l}<5 \text { years } \\
<3 \text { months } \\
<6 \text { months } \\
\text { Adult }\end{array}$ \\
\hline & $\begin{array}{l}\text { Crain and Gershel }{ }^{27} \\
\text { Kashani and Faraday } \\
\text { Herzog } \\
\text { He }^{29}\end{array}$ & $\begin{array}{l}1990 \\
1989 \\
1989\end{array}$ & $\begin{array}{l}\text { USA } \\
\text { USA } \\
\text { USA }\end{array}$ & $\begin{array}{l}\text { Hospital outpatient } \\
\text { Hospital inpatient } \\
\text { Hospital outpatient }\end{array}$ & $\begin{array}{l}81 \\
126 \\
112\end{array}$ & $\begin{array}{l}22 \\
17 \\
36\end{array}$ & $\begin{array}{l}<2 \text { months } \\
1 \text { month to } 2 \text { years } \\
<1 \text { year }\end{array}$ \\
\hline
\end{tabular}

*Outpatient data not included in analysis as they did not accurately define UTI events.

$\mathrm{RCT}$, randomised controlled trial; UTI, urinary tract infection.

heterogeneity between the cohort studies $\left(\chi^{2}=82.48, \mathrm{df}=3\right.$, $\mathrm{p}<0.001$ ), with the study by To et al ${ }^{1}$ being the outlier. When the study by To was excluded, the heterogeneity between cohort studies was non-significant $\left(\chi^{2}=0.88, \mathrm{df}=2, \mathrm{p}=0.64\right)$.

The reasons for the observed heterogeneity are uncertain but may reflect varying methods of circumcision and UTI ascertainment, and the differing follow up periods of the studies.

In relation to circumcision status, To et al ${ }^{1}$ were able to access information regarding circumcision beyond the neonatal period and excluded subjects circumcised after the age of one month. The three other cohort studies were unable to account for circumcisions undertaken after the neonatal inpatient stay. If there were significant numbers of circumcisions carried out beyond the neonatal inpatient period, these studies would underestimate UTI occurrence in the circumcised group and thus result in misclassification.

\section{Follow up duration}

The study by $\mathrm{To}^{1}$ extended follow up to as long as three years compared with a maximum of one year for the other cohort studies. To showed a progressive reduction in the protective effect of circumcision on UTI with increasing age. Thus the inclusion of older subjects may have contributed to the difference in results. The Craig study, ${ }^{23}$ however, which stratified for age, found no such difference, but was small and may have been subject to type II error.

Table 2 Quality of cohort studies examining the effect of circumcision on urinary tract infection in male subjects

\begin{tabular}{|c|c|c|c|c|c|c|c|}
\hline \multirow[b]{2}{*}{ Reference } & \multirow[b]{2}{*}{ Definition of UTI } & \multirow{2}{*}{$\begin{array}{l}\text { Determination of } \\
\text { circumcision status }\end{array}$} & \multirow[b]{2}{*}{ Exclusion criteria } & \multirow[b]{2}{*}{ Follow up } & \multicolumn{3}{|c|}{$\begin{array}{l}\text { Adjustment for } \\
\text { confounding variables }\end{array}$} \\
\hline & & & & & Age & SES & Ethnicity \\
\hline $\begin{array}{l}\text { Schoen } \\
\text { et } a R^{2}\end{array}$ & $\begin{array}{l}>10^{8} / / \text { pure growth in } 90 \% \\
\text { from any means of collection } \\
\text { Source unknown in } 4 \% \\
\text { Determined by retrospective } \\
\text { database search and } \\
\text { confirmed by review of case } \\
\text { records of random selection of } \\
52 \text { cases }\end{array}$ & $\begin{array}{l}\text { Inpatients: ICD-9 coding for } \\
\text { circumcision in neonatal } \\
\text { hospital stay } \\
\text { Outpatients: ICD-9 from } \\
\text { KPNC database for } \\
\text { outpatient circumcision }\end{array}$ & $\begin{array}{l}\text { Patient not within health plan for full } \\
\text { duration of study }\end{array}$ & $<1$ year & No & No & No \\
\hline To et $a l^{1}$ & $\begin{array}{l}\text { Inpatients: ICD-9 coding } \\
\text { (kidney infection, cystitis, } \\
\text { urethritis or urinary tract } \\
\text { infection) } \\
\text { Outpatients: OHIP data } \\
\text { Determined by retrospective } \\
\text { database search }\end{array}$ & $\begin{array}{l}\text { The Canadian classification } \\
\text { procedure code during the } \\
\text { first month of life }\end{array}$ & $\begin{array}{l}\text { Older than } 1 \text { month of age at time } \\
\text { of circumcision, multiple birth, } \\
\text { stillbirth, birth complications and } \\
\text { lack of health care number }\end{array}$ & $\begin{array}{l}2-3 \text { years for } \\
\text { inpatient } \\
\text { cases } \\
<1 \text { year for } \\
\text { outpatient } \\
\text { cases }\end{array}$ & No & Yes & No \\
\hline $\begin{array}{l}\text { Wiswell and } \\
\text { Hachey }^{6}\end{array}$ & $\begin{array}{l}\text { Not specified } \\
\text { Determined by retrospective } \\
\text { database search }\end{array}$ & $\begin{array}{l}\text { US Army patient } \\
\text { administration systems and } \\
\text { biostatistics activity } \\
\text { database }\end{array}$ & $\begin{array}{l}\text { Bag urine specimen, congenital } \\
\text { abnormality, or predisposition to } \\
\text { UTI (not specified) }\end{array}$ & $<1$ year & No & No & No \\
\hline $\begin{array}{l}\text { Wiswell } \\
\text { et }\left.a\right|^{5}\end{array}$ & $\begin{array}{l}\text { Not specified } \\
\text { Determined by retrospective } \\
\text { database search }\end{array}$ & $\begin{array}{l}\text { US Army patient } \\
\text { administration systems and } \\
\text { biostatistics activity } \\
\text { database }\end{array}$ & $\begin{array}{l}\text { Congenital abnormality or } \\
\text { predisposition to UTI (not specified) }\end{array}$ & $<1$ year & No & No & No \\
\hline
\end{tabular}

ICD-9, International Classification of Diseases, 9th revision; KPNC, Kaiser Permanente Medical Care Program, Northern California, USA; OHIP, Ontario Health Insurance Plan; SES, socioeconomic status. 
Table 3 Quality of case-control studies examining the effect of circumcision on urinary tract infection in male subjects

\begin{tabular}{|c|c|c|c|c|c|c|c|}
\hline \multirow[b]{2}{*}{ Reference } & \multirow[b]{2}{*}{ Definition of UTI } & \multirow{2}{*}{$\begin{array}{l}\text { Determination of } \\
\text { circumcision status }\end{array}$} & \multirow[b]{2}{*}{ Exclusion criteria } & \multirow[b]{2}{*}{ Origin of controls } & \multicolumn{3}{|c|}{$\begin{array}{l}\text { Adjustment for confounding } \\
\text { variables }\end{array}$} \\
\hline & & & & & Age & SES & Ethnicity \\
\hline Newman et $a f^{24}$ & $\begin{array}{l}\text { Bag urine or clean catch } \\
\geqslant 10^{7} / / \\
\mathrm{CSU} \geqslant 2 \times 10^{6} / I \\
\mathrm{SPA} \geqslant 10^{4} / /\end{array}$ & Standard questionnaire & $\begin{array}{l}\text { No fever }>38^{\circ} \mathrm{C} \text { or urine } \\
\text { collected at presentation } \\
\text { Uncertain circumcision } \\
\text { status }\end{array}$ & $\begin{array}{l}\text { Patients presenting to } \\
\text { non-hospital outpatients } \\
\text { with a fever }\end{array}$ & No & No & No \\
\hline Craig et $a^{23}$ & $\begin{array}{l}\mathrm{CSU} / \mathrm{SPA} \geqslant 10^{6} / \mathrm{I} \\
\mathrm{MSU} \geqslant 10^{8} / \mathrm{I}\end{array}$ & $\begin{array}{l}\text { Direct questioning of } \\
\text { parents or direct } \\
\text { examination }\end{array}$ & $\begin{array}{l}\text { Past history of UTI or } \\
\text { urinary tract abnormality; } \\
\text { neurological or skeletal } \\
\text { abnormality predisposing } \\
\text { to UTI }\end{array}$ & $\begin{array}{l}\text { Patients presenting to } \\
\text { hospital emergency } \\
\text { department for any } \\
\text { reason other than those } \\
\text { diagnosed with UTI }\end{array}$ & Yes & No & No \\
\hline $\begin{array}{l}\text { Rushton and } \\
\text { Majd }^{25}\end{array}$ & $\begin{array}{l}\mathrm{MSU} \geqslant 10^{8} / \mathrm{I} \\
\mathrm{CSU} \geqslant 10^{7} / \mathrm{I}\end{array}$ & $\begin{array}{l}\text { Cases: "prospectively" } \\
\text { found but not specified } \\
\text { Controls: documentation } \\
\text { in medical record but no } \\
\text { further details given }\end{array}$ & $\begin{array}{l}\text { Prolonged neonatal } \\
\text { hospital admission or } \\
\text { uncertain circumcision } \\
\text { status }\end{array}$ & $\begin{array}{l}\text { Patients admitted with } \\
\text { febrile upper respiratory } \\
\text { tract infection. Matched } \\
\text { for age, race, and SES }\end{array}$ & No & Yes & Yes \\
\hline Spach et $a^{26}$ & $\begin{array}{l}\text { MSU }>10^{6} / \text { I growth } \\
\text { along with one or more } \\
\text { symptoms }\end{array}$ & Examination & $\begin{array}{l}\text { No clear exclusion } \\
\text { criteria }\end{array}$ & $\begin{array}{l}\text { Patients without } \\
\text { bacteriuria presenting to } \\
\text { outpatient clinic }\end{array}$ & Yes & No & Yes \\
\hline $\begin{array}{l}\text { Crain and } \\
\text { Gershel }^{27}\end{array}$ & $\begin{array}{l}\text { Bag urine } \geqslant 10^{4} / / \\
\mathrm{CSU} \geqslant 10^{4} / / \\
\mathrm{SPA} \geqslant 10^{2} / \mathrm{I}\end{array}$ & $\begin{array}{l}\text { Documentation in medical } \\
\text { records no further details } \\
\text { given }\end{array}$ & Absence of fever & $\begin{array}{l}\text { Patients presenting to } \\
\text { hospital with fever and } \\
\text { without a discharge } \\
\text { diagnosis of UTI }\end{array}$ & No & No & No \\
\hline $\begin{array}{l}\text { Kashani and } \\
\text { Faraday }^{28}\end{array}$ & $\mathrm{CSU} / \mathrm{SPA} \geqslant 10^{8} / 1$ & $\begin{array}{l}\text { Documentation in medical } \\
\text { record }\end{array}$ & $\begin{array}{l}\text { Urinary tract abnormality, } \\
\text { inadequate } \\
\text { documentation of } \\
\text { specimen type or age } \\
<1 \text { month }\end{array}$ & $\begin{array}{l}\text { Patients presenting to } \\
\text { outpatients clinics for } \\
\text { unrelated reasons }\end{array}$ & No & No & Yes \\
\hline Herzog $^{29}$ & $\mathrm{CSU} / \mathrm{SPA} \geqslant 10^{7} / \mathrm{I}$ & $\begin{array}{l}\text { Documentation in medical } \\
\text { record or direct contact } \\
\text { with family if unclear in } \\
\text { medical records }\end{array}$ & $\begin{array}{l}\text { Anatomical abnormality, } \\
\text { past history of UTI, } \\
\text { myelodysplasia, } \\
\text { uncertain circumcision } \\
\text { status or race, and } \\
\text { equivocal culture results }\end{array}$ & $\begin{array}{l}\text { Patients who presented to } \\
\text { emergency with a febrile } \\
\text { illness and had a SPA or } \\
\text { CSU which was negative }\end{array}$ & Yes & Yes & Yes \\
\hline
\end{tabular}

\section{UTI diagnostic criteria}

The Wiswell studies ${ }^{5}$ did not specify diagnostic criteria for defining UTI, while the study by To et al ${ }^{1}$ used International Classification of Diseases, 9th revision and Ontario Health Insurance Plan data coding, and the Schoen study ${ }^{22}$ used laboratory data. These differing definitions of UTI are an unlikely source of variability in the results.

The study by To was also the only one to account for repeat episodes of UTI in individual patients and showed that the contributory effect of these repeat episodes was minimal. The other studies recorded the overall number of UTI episodes rather than the number of patients with UTI.

\section{Case-control studies}

All seven case-control studies included ${ }^{23-29}$ showed benefit, with a combined OR of 0.13 ( $95 \%$ CI, 0.07 to 0.23 ). There was no significant heterogeneity between the studies within this group $\left(\chi^{2}=8.15, \mathrm{df}=6, \mathrm{p}=0.2\right)$.

\section{All studies}

The summary OR across study types when all three were combined was 0.13 (95\% CI, 0.08 to 0.20$)$. There was no significant heterogeneity between the three subgroups $\left(\chi^{2}=0.16, \mathrm{df}=2, \mathrm{p}=0.9\right)$. However, significant heterogeneity was observed between the individual studies $\left(\chi^{2}=90.63\right.$, $\mathrm{df}=11, \mathrm{p}<0.00001)$ owing to the inclusion of the To study. ${ }^{1}$ Without To ${ }^{1}$ there was no significant heterogeneity between the remaining studies $\left(\chi^{2}=10.92, \mathrm{df}=10, \mathrm{p}<0.4\right)$.

\section{DISCUSSION}

The odds of UTI in circumcised boys are about 0.1 when compared with uncircumcised boys. This represents a reduction in odds of nearly $90 \%$.

What is striking from these results is the level of homogeneity in the effect across a variety of settings and the three different study designs. An OR of 0.13 reflects a substantial reduction and makes residual confounding an unlikely source of the observed association.

The temporal and biological plausibility of circumcision (by modifying preputial colonisation ${ }^{28}{ }^{30}$ and thus decreasing the potential source of bacteria causing UTI) adds weight to the association being a genuine effect of circumcision on UTI. However, colonisation may also increase the risk of contamination of bag urine collections, leading to false positive urine cultures in uncircumcised boys. The method of urine collection was poorly defined or included bag urine collections in a significant number of the studies in this systematic review, ${ }^{1} 56222327$ thus potentially overestimating the rate of UTI in the uncircumcised group. In the remaining studies, clean catch urine or suprapubic tap was the method of urine collection and the favourable odds ratio was maintained even when the above bias was minimised.

The principal weakness of this systematic review is that it is dominated by observational studies of variable quality. The one randomised controlled trial identified had a small sample size and failed to achieve independent statistical significance. However, the point estimate of OR for this randomised 


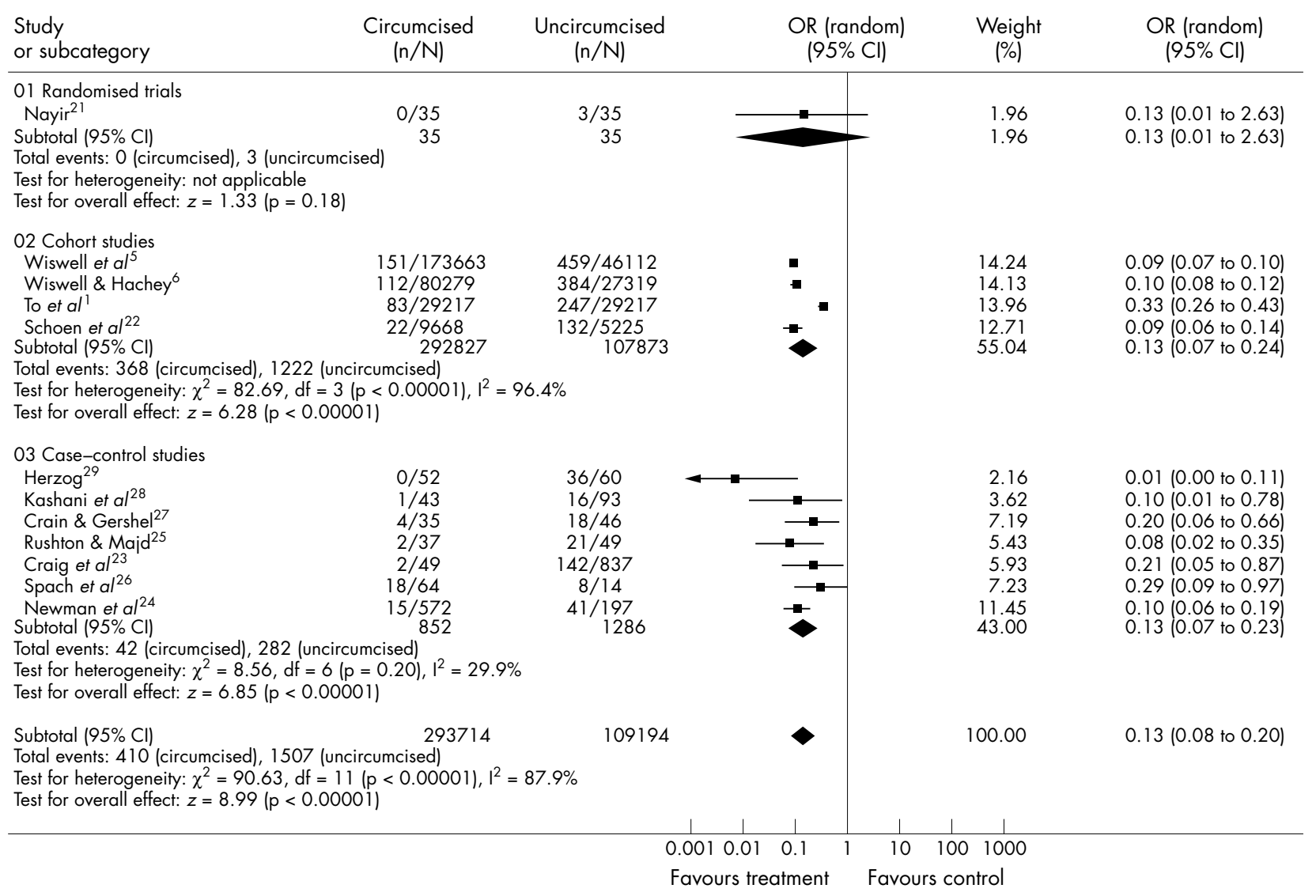

Figure 2 Meta-analysis of studies examining the effect of circumcision on urinary tract infection in male subjects.

controlled trial was identical to that of the other studies included, and to our combined result.

Another shortcoming is that the majority of studies measured episodes of UTI rather than the number of patients experiencing UTI. Thus the prevalence of repeat UTI in these populations is not known and may have biased the observed results if the distribution of patients with repeat UTI was unequal between the two treatment groups. However, as seen in the To study, ${ }^{1}$ the number of recurrences is likely to be small and an unlikely explanation for the large difference observed between the circumcised and uncircumcised groups.

Existing systematic reviews on the association between circumcision and UTI by Amato in $1992^{4}$ and Wiswell in $1993^{6}$ also concluded that circumcision was associated with a protective effect on UTI, with ORs of 0.07 (95\% CI, 0.06 to 0.09 ) and 0.08 (0.07 to 0.09), respectively, being obtained. These results imply a more protective effect than we found in our analysis. This difference may be explained by the fact that we included several additional studies ${ }^{11} 21232426$ published since the earlier meta-analyses. We also excluded duplicate data from our analysis and examined heterogeneity between the available data.

While circumcision is protective for UTI, the overall riskbenefit derived from circumcision in preventing UTI is not easily quantifiable, as the incidence of important sequelae of UTI (sepsis, permanent renal damage, hypertension, and chronic renal failure) are not known. The complication rate of circumcision is documented to be between $2 \%$ and $10 \%,{ }^{11}{ }^{12}$ and no data are available on the relative risks and benefits of circumcision. Thus we have used a conservative estimate of circumcision complications of $2 \%$ and assumed equal utility for benefits and harms in the following analysis.

Existing studies suggest that from $1 \%$ to $2 \%$ of boys can be expected to experience a UTI within the first 10 years of life. ${ }^{23} 3132$ From the data included in this meta-analysis, the UTI rate in the uncircumcised group was approximately $0.5 \%$ and may reflect a shorter follow up period than other studies. Furthermore, studies ${ }^{32}{ }^{33}$ have shown a recurrence rate of UTI in preschool children of around $10 \%$ in the absence of

Table 4 Benefit versus harm for circumcision in preventing urinary tract infection in boys at different levels of risk for UTI per 1000 boys, assuming a complication rate of $2 \%$ and an odds ratio of 0.13

\begin{tabular}{lcclcl}
\hline & $\begin{array}{l}\text { Risk of } \\
\text { UTI }\end{array}$ & $\begin{array}{l}\text { UTI in } \\
\text { Uncircumcised } \\
\text { (n) }\end{array}$ & $\begin{array}{l}\text { UTI in } \\
\text { circumcised } \\
\text { (n) }\end{array}$ & $\begin{array}{l}\text { UTI prevented by } \\
\text { circumcision (n) }\end{array}$ & $\begin{array}{l}\text { Complications of } \\
\text { circumcision (n) }\end{array}$ \\
\hline Normal & $1 \%$ & 10 & 1 & 9 & 20 \\
Past UTI & $10 \%$ & 100 & 13 & 87 & 20 \\
High grade VUR & $30 \%$ & 300 & 39 & 261 & 20 \\
\hline
\end{tabular}




\section{What is already known on this topic}

- Various paediatric societies have developed position statements on circumcision. These statements generally conclude that there is insufficient evidence to recommend routine neonatal circumcision but consider it justified in recurrent balanitis, true phimosis, and urinary tract infection

- Lack of a clear consensus on the magnitude of the benefits of circumcision may reflect variability in the different methods used to search and critically appraise the available reports

\section{What this study adds}

- Meta-analysis of existing research shows that circumcision substantially reduces the risk of urinary tract infection (UTI)

- The data do not support the routine circumcision of normal boys to prevent UTI

- Circumcision should be considered in boys with a past history of recurrent UTI or high grade Igrade 3 and above) vesicoureteric reflux, as the benefit outweighs the risk of complications in these cases

significant urinary tract abnormality. The recurrence rate increases to $30 \%$ in children with vesicoureteric reflux of grade 3 and above. ${ }^{32}{ }^{33}$ We have used these estimates of UTI incidence and circumcision complication rate to construct a table of harms and benefits of circumcision (table 4).

This shows that the benefit of circumcision on UTI only outweighs the risk in boys who have had UTI previously and have a predisposition to repeated UTI. As this analysis has used a conservative circumcision complication rate of $2 \%$, if the complication rate were in reality higher the risk-benefit analysis may not favour circumcision even in the higher risk populations.

In conclusion, the data we present do not support the routine circumcision of normal boys with standard risk in order to prevent UTI. However, our data suggest that circumcision of boys with higher than normal risk of UTI should be considered. As there is no direct evidence of the effect of circumcision on UTI in this group, confirmation through a randomised trial of circumcision in high risk patients would be beneficial. Using an OR of 0.2 (the upper limit of the $95 \%$ CI of the combined OR found in this study) and a power of $80 \%$, the sample size required to study this hypothesis would be 140 (70 in each treatment arm), assuming a recurrence risk of $10 \%$.

Until this additional information is available, the present data do not support the routine circumcision of boys to prevent UTI. However, circumcision should be considered in those with recurrent UTI or significantly increased risk of UTI.

\footnotetext{
Authors' affiliations

D Singh-Grewal, J Macdessi, Department of Paediatrics and Child Health, The Children's Hospital at Westmead, Sydney, Australia J Craig, Centre for Kidney Research, The Children's Hospital at Westmead, Sydney, Australia
}

Competing interests: none declared

\section{REFERENCES}

1 To T, Agha M, Dick PT, et al. Cohort study on circumcision of newborn boys and subsequent risk of urinary-tract infection. Lancet 1998;352:1813-16.

2 American Academy of Pediatrics. Circumcision policy statement. American Academy of Pediatrics. Task Force on Circumcision. Pediatrics 1999; 103:686-93.

3 Royal Australasian College of Physicians. Paediatrics and Child Health Division. Policy statement on circumcision, 2002, www.racp.edu.au/hpu/ paed/circumcision/index.htm\#toc.

4 Amato D, Garduno-Espinosa J. Circumcision in the newborn child and risk of urinary tract infection during the first year of life. A meta-analysis. Bol Med Hosp Infant Mexico 1992;49:652-8.

5 Wiswell TE, Enzenauer RW, Holton ME, et al. Declining frequency of circumcision: implications for changes in the absolute incidence and male to female sex ratio of urinary tract infections in early infancy. Pediatrics 1987;79:338-42.

6 Wiswell TE, Hachey WE. Urinary tract infections and the uncircumcised state: an update. Clin Pediatr 1993;32:130-4.

7 Cook LS, Koutsky LA, Holmes KK. Circumcision and sexually transmitted diseases. Am J Public Health 1994;84:197-201.

8 Schoen EJ. The relationship between circumcision and cancer of the penis. Cancer J Clin 1991;41:306-9.

9 Dewan PA, Tieu HC, Chieng BS. Phimosis: is circumcision necessary? $J$ Paediatr Child Health 1996;32:285-9.

10 Castellsagué X, Bosch FX, Muñoz N, et al. Male circumcision, penile human papillomavirus infection, and cervical cancer in female partners. N Engl J Med 2002;346:1105-12.

11 Williams N, Kapila L. Complications of circumcision. Br J Surg 1993;80:1231-6

12 Kaplan GW. Complications of circumcision. Urol Clin North Am 1983;10:543-9.

13 Griffiths DM, Atwell JD, Freeman NV. A prospective survey of the indications and morbidity of circumcision in children. Eur Urol 1985;1 1:184-7.

14 Harkavy KL. The circumcision debate. Pediatrics 1987;79:649-50.

15 Canadian Paediatric Society. Neonatal circumcision revisited. Fetus and Newborn Committee, Canadian Paediatric Society. Can Med Assoc J $1996 ; 154: 769-80$.

16 Shaneyfelt TM, Mayo-Smith MF, Rothwangl J. Are guidelines following guidelines? The methodological quality of clinical practice guidelines in the peer-reviewed medical literature. JAMA 1999;281:1900-5.

17 Begg C, Cho M, Eastwood S, et al. CONSORT statement - improving the quality of reporting of randomized controlled trials. JAMA 1996;276:637-9.

18 Stroup DF, Morton SC, Olkin I, et al. Meta-analysis of observational studies in epidemiology: a proposal for reporting. Meta-analysis of Observational Studies in Epidemiology (MOOSE) group. JAMA 2000;283:2008-12.

19 RevMan Analyses [Computer program]. Version 1.0 for Windows. In: Review Manager (RevMan) 4.2. Oxford: The Cochrane Collaboration, 2002

20 Higgins JPT, Thompson SG, Deeks JJ, et al. Measuring inconsistency in metaanalysis. BMJ 2003;327:557-60.

21 Nayir A. Circumcision for the prevention of significant bacturia in boys. Paediatr Nephrol 2001; 16:1129-34

22 Schoen EJ, Colby CJ, Ray GT. Newborn circumcision decreases incidence and costs of urinary tract infections during the first year of life. Pediatrics 2000; 105:789-93.

23 Craig JC, Knight JF, Sureshkumar P, et al. Effect of circumcision on incidence of urinary tract infection in preschool boys. J Pediatr 1996;128:23-27.

24 Newman TB, Bernzweig JA, Takayama Jl, et al. Urine testing and urinary tract infections in febrile infants seen in office settings: The Paediatric Research Office Settings' Febrile Infant Study. Arch Pediatr Adolesc Med 2002:156:44-54.

25 Rushton HG, Majd M. Pyelonephritis in male infants: how important is the foreskin? J Urol 1992;148:733-6.

26 Spach DH, Stapleton AE, Stamm WE. Lack of circumcision increases the risk of urinary tract infection in young men. JAMA 1992;267:679-81.

27 Crain EF, Gershel JC. Urinary tract infections in febrile infants younger than 8 weeks of age. Pediatrics 1990;86:363-7.

28 Kashani IJ, Faraday MS. The risk of urinary tract infection in uncircumcised male infants. Int Pediatr 1989;4:44-5.

29 Herzog LW. Urinary tract infections and circumcision. A case-control study. Am J Dis Child 1989;143:348-50.

30 Wiswell TE, Miller GM, Gelston HM, et al. Effect of circumcision status on periurethral bacterial flora during the first year of life. J Pediatr 1988;113:442-6.

31 Hellstrom A, Hanson E, Hansson S, et al. Association between urinary symptoms at 7 years old and previous urinary tract infection. Arch Dis Child 1991;66:232-4.

32 Winberg J, Anderson HJ, Bregstom T, et al. Epidemiology of symptomatic urinary tract infection in childhood. Acta Paediatr Scand 1974;252(suppl): 1-20.

33 Panaretto KS, Craig JC, Knight JF, et al. Risk factors for recurrent urinary tract infection in preschool children. J Paediatr Child Health 1999;35:454-9. 